UDK: 811.411.21:371.3]:005.336

Izvorni naučni rad

Primljeno: 06.05.2019.

Prihvaćeno za štampu: 31.5.2019.

dr. sci. Hajrudin Hodžić, docent

Univerzitet u Bihaću

Islamski pedagoški fakultet

bajrudinhodzio@gmail.com

\title{
BITNI FAKTORI ZA USPJEH U NASTAVI ARAPSKOG JEZIKA
}

\section{Sažetak}

Benefiti $i$ koristi poznavanja nekog stranog jezika su nemjerljivi i predstavljaju značajan motiv za učenje stranih jezika, posebno onih svjetski najrasprostranjenijih. Učenje bilo kojeg stranog jezika je naporan i mukotrpan proces, koji iziskuje mnogo strpljenja i odricanja. Mecutim, onoga trenutka kada se veći dio nekog jezika usvoji gubi se osjećaj umora koji je opterećivao osobu koja ga je postepeno usvajala.

Mnogo je faktora koji mogu utjecati na efikasnost i brzinu usvajanja jezika, ali glavnu ulogu u čitavom procesu zauzima nastavnik, koji treba da uspješno upravlja procesom učenja, kako bi uloženi trud polučio što kvalitetnije rezultate.

Cilj ovoga rada jeste ukazati na najbitnije faktore za uspjeh u nastavi arapskog jezika, zatim napraviti osvrt na trenutna iskustva na polju podučavanja arapskog jezika, ali i ponuditi odredene ideje i pristupe koji će pomoći da se razvijaju nove vještine kod nastavnika arapskog, ali i svakog drugog stranog jezika.

Ključne riječi: arapski jezik, metode, faktori uspjeha, nastava, strani jezik

\section{Uvod}

Arapski jezik je, pored mandarinskog, portugalskog, indijskog i engleskog, jedan od najraširenijih jezika svijeta. Ako se u obzir uzme činjenica da je arapski svijet područje sa najjačim prirodnim natalitetom, onda nam to dovoljno jasno govori o kakvom se bitnom 
jeziku radi. Uvažavajući te činjenice, većina univerziteta u svijetu je prepoznala značaj arapskog jezika i neki od njih su još prije nekoliko desetljeća utemeljili katedru ili institut za arapski jezik ili orijentalistiku.

Jezik sa ovakvom pozicijom u svijetu zaslužuje da mu se pridaje velika pažnja i da za njega vlada veliki interes u čitavom svijetu. Pored svega navedenog, svi muslimanski narodi, a samim tim i Bošnjaci imaju dodatni motiv za njegovo izučavanje ${ }^{1}$, a on se manifestuje u njihovoj pripadnosti islamu i ljubavi koju gaje prema jeziku posljednje Božije objave, a to je razlog zašto je popularnost ovoga jezika na našim prostorima oduvijek bila na visokoj razini. ${ }^{2}$

Učenje i usvajanje leksike bilo kojeg stranog jezika predstavlja mukotrpan proces koji često traje i nekoliko godina, a ponekad i ne poluči željene rezultate, u smislu uspješnog usvajanja stranog jezika.

Na putu učenja nekog jezika, učenik ili student se susreće sa brojnim preprekama različite prirode, koje otežavaju učenje stranog jezika ili ih obeshrabre do te mjere da odustane od tog jezika i pomire se sa činjenicom da je on za njih neosvojiva tvrđava. Te prepreke su često rezultat brojnih grešaka koje su produkt neiskustva i lošeg pristupa nastavnika, nedakvatne literature, te brojnih drugih grešaka koje osobu, koja ima želju da nauči neki od stranih jezika, obeshrabre i predstave učenje istog nemogućom misijom.

Nakon trinaest godina iskustva u oblasti nastave arapskog jezika, smatram da kroz ovaj rad mogu ponuditi nekoliko konkretnih savjeta i smjernica kako predavati strani jezik i kako zainteresovati učenike i studente koji izučavaju neki od stranih jezika. Svemu ove bih dodao i činjenicu da na ovom planu imam značajno iskustvo recepijent, jer sam proveo značajan dio vremena kao polaznik brojnih kurseva drugih stranih jezika, gdje sam, pored učenja same materije, u velikoj mjeri bio

\footnotetext{
${ }^{1}$ Iskustva Islamskog pedagoškog fakulteta u Bihaću u organiziranju kurseva arapskog jezika, gdje se svake godine prijavi skoro stotinjak polaznika dovoljno govori u prilog ovoj konstataciji.

${ }^{2}$ Mnoštvo je motiva za izučavanja arapskog jezika. Nekada su to bila djela naših i drugih učenjaka koji su pisali na tom jeziku, a danas je to sve veći priliv arapskih turista i migranata u našu zemlju, i to u omjeru koji se nekada nije mogao ni zamisliti.
} 
fokusiran na metode koje su koristili predavači na spomenutim kursevima.

Sredinom oktobra 2017. godine pripala mi je čast da budem jedan od izlagača na petodnevnom seminaru „Metode unapređenja vještina učenja arapskog jezika kod učenika i studenata" u organizaciji Islamske organizacije za obrazovanje, nauku i kulturu (ISESCO) i Svjetske organizacije za afirmaciju arapskog jezika. Tom prilikom sam imao izlaganje na temu „Djelotvorne strategije i pristupi u nastavi arapskog jezika u BiH“. S obzirom na značaj same teme koju sam izlagao smatram da je korisno da istu proširim i publikujem u ovom zborniku.

Iako se tema ovoga rada o kojoj govorim veže za arapski jezik, međutim ona se može odnositi i na druge strane jezike, jer su izazovi sa kojima se nastavnik i učenik suočavaju veoma slični, bez obzira o kojem se stranom jeziku radi. Naravno, u svemu tome neophodno je uvažavati određene specifičnosti koje ima svaki od jezika.

Kontinuirano propitivanje kvaliteta metoda koje koristimo u nastavi i traganje za novim predstavlja bitan preduvjet uspjeha same nastave. To propitivanje mora da bude stalan proces ukoliko predavač želi postići visok nivo u kvaliteti nastave, a neće u tome uspjeti ukoliko ne bude inovirao i konstatno tragao za novim metodama.

Ovaj rad je skroman doprinos iz ove oblasti na našem jeziku, ali se nadamo da neće biti zadnji koji će obrađivati ovako bitnu problematiku, posebno ako se ima na umu značaj kvalitetno provedenog vremena $u$ nastavi stranog jezika, ali i ljubavi koju usađujemo u srca učenika i studenata spram stranog jezika kojeg ih podučavamo.

\section{Neophodni preuduvjeti za uspjeh u nastavi stranog jezika}

Da bi nastava bila uspješna i efikasna, neophodno je osigurati bitne preduvjete koji će pomoći da se postignu ishodi učenja koji su definisani prilikom izrade samog plana i programa.

S obzirom na činjenicu da je nastava složen proces, koji se sastoji od mnogo činbenika, mi smo u našem radu, pokušavajući ponuditi određena rješenja, htjeli staviti fokus na pet najvažnijih faktora, a to su: učenik / student, nastavnik, nastavni program, udžbenik, te okruženje u kojem se realizuje nastava. Da bismo što bolje shvatili značaj ovih 
faktora u cjelokupnom procesu nastave arapskog jezika, bitno je temeljito razraditi svaki od ovih pet faktora.

\section{Prvi faktor: Učenik / student}

Nema sumnje da osoba koja pristupa učenju stranog jezika mora biti, prije svega, motivirana za učenje (Lightbown\&Spada 2014: 347.), a to se postiže na različite načine. Jedan od načina motiviranja jeste i upoznavanje sa značajem stranog jezika koji se izučava (u našem slučaju arapskog jezika), sa svima mogućnostima koje se otvaraju osobi koja uspije da nauči taj jezik (poput činjenice da se poznavanjem arapskog jezika stvaraju predispozicije za ispravno razumijevanje Kur'ana, Božije riječi, zatim upoznavanje sa kulturom i naučnim blagom kojeg su svi muslimanski narodi stoljećima stvarali na tom jeziku, kao i mogućnost ostvarivanja komunikacije sa više od 400 miliona ljudi, koji govore ovim jezikom), kao i otklanjanje svih prepreka koje stoje kao prepreka na putu usvajanja stranog jezika.

Često se postavlja pitanje kako motivirati učenika koji, pored činjenice da mu je to jedan od mnogih predmeta predviđenih Planom i programom, nema nikakve predstave o tom jeziku, niti bi ga izabrao za izučavanje kao stranog jezika. Takva je, najčešće, situacija sa većinom stranih jezika koji se uče u našim školama. Međutim, nastavnik stranog jezika se treba izboriti za „svoje mjesto pod suncem“ i tu dolazi do izražaja njegova motiviranost, upornost i kreativnost, o čemu će više biti govora prilikom obrade narednog faktora. Međutim, bitno je razbiti predrasudu da je arapski jezik težak jezik, da ga je nemoguće naučiti, te da predstavlja „noćnu moru“ učenicima ili studentima.

To se, prije svega, postiže blagošću i lijepim odnosom prema učenicima, da bi se steklo povjerenje učenika, odnosno studenata. Pojedini nastavnici su mišljenja da visok nivo predmeta mogu postići isključivo strogošću, što je pogrešno uvriježeno mišljenje. Naprotiv, blag odnos i blaga narav nastavnika mogu značajno rušiti barijere između predmeta i učenika, odnosno studenata.

Nastavnik treba uložiti maksimalan napor kako bi se učenje stranog jezika omililo učenicima ili studentima, kako bi njihov interes za njegovo izučavanje bio na visokom nivou, čime bi uklonili značajnu prepreku u tom procesu. U tom kontekstu, Lightbown\&Spada smatraju 
da od prostorije u kojoj se uči strani jezik treba načiniti „prostor koji će motivirati učenike“ (Lightbown\&Spada 2014: 347). Prema tome, jaka motiviranost je oduvijek bila ključni faktor za lakše savladavanje stranih jezika.

Imajući u vidu činjenicu da arapski alfabet predstavlja značajnu prepreku u procesu usvajanja arapskog jezika, kao i sama leksika arapskog jezika, nastavnik mora iznalaziti rješenja za prevalizaženje tih prepreka ciljem motiviranja učenika / studenata za aktivnije učešće u nastavi.

\section{Drugi faktor: Nastavnik}

Drugi i, ali po značaju, najvažniji faktor nastavnog procesa jeste nastavnik, koji, kako to kaže jedna izreka „može i uz loš udžbenik postići izniman uspjeh u svom radu“. Nastavnik igra ključnu ulogu u ovom procesu i s pravom se najveća pažnja posvećuje upravo njemu, s obzirom da je on rukovodilac nastavnog procesa i osoba koja mora da zna u kom pravcu ga treba usmjeravati.

Prije nabrajanja bilo kakvih uvjeta koji trebaju krasiti nastavnika stranog jezika, ključna pretpostavka za njegov uspješan rad jeste njihova individualna motiviranost da na planu širenja stranog jezika, a posebno arapskog jezika, jezika Kur'ana i islamske tradicije, jezika islamske kulture i civilizacije, usadi u srca učenika i studenata ljubav i naklonost prema tom jeziku, kako bi savladavanje eventualnih prepreka bilo lakše. Ako nastavnik nije motiviran da svoj posao obavlja odgovorno i sa visokim stepenom posvećenosti, onda je čitav proces doveden u pitanje i u takvim okolnostima je teško postići značajne rezultate, jer je nastavnik, kako smo to istakli, centralna figura čitavog procesa.

U stručnoj literaturi se navode brojne sposobnosti kojima se treba okititi nastavnik stranog jezika, od kojih ističemo: jezičku, kulturološku i komunikološku sposobnost (Ṭ'ayma 2004: 172). Pored kvalitetnog ovladavanja jezikom kojeg podučava druge, nastavnik mora imati široku naobrazbu, kvalitetan uvid u druge naučne oblasti, kako bi tu sposobnost stavio u službu učenja stranog jezika, kojeg prenosi svojim učenicima / studentima. Također, njegove komunikacijske vještine i 
sposobnosti moraju biti na zavidnom nivou, jer interakcija u nastavi stranog jezika zauzima značajno mjesto, ako ne i presudno.

Dobra pripremljenost nastavnika, prema Purkoviću, manifestuje se kroz nekoliko segmenata: materijalna, psihološka, organizacijska i metodička pripremljenost za nastavu.

Ukoliko neka od ovih sposobnosti bude dovedena u pitanje, ona može bitno negativno utjecati na sam nastavni proces, jer bi to predstavljalo bitan, suštinski nedostatak koji može dovesti u pitanje kvalitetno usvajanje neophodnog znanja.

Nastavnik mora, kako bi zainteresirao svoje učenike / studente, koristiti raznolika sredstva $\mathrm{i}$ iznalaziti različite metode, ali sve s ciljem da se stvori atmosfera koja će pomoći da se održi učenička / studentska pažnja tokom sati nastave stranog jezika.

\section{Treći faktor: Nastavni program}

Nastavni plan i program igra veoma značajnu ulogu u ovom procesu. Međutim, pogrešno koncipiran plan i program može dovesti u pitanje kvalitet čitavog procesa, jer je profesor dužan i pozvan da ga se pridržava i radi po njemu. Zbog toga treba obratiti posebna pažnja da plan i program bude adekvatan i da se njim postižu željeni ishodi učenja. S toga, prilikom izrade plana i programa rada bitno je imati i vidu cilj izučavanja stranog jezika, ishode učenja, starosnu dob učenika ili studenta, atraktivnost sadržaja koji se izučava, itd. (Al-'Amīn 2008: 163).

Posebno treba naglasiti da se prilikom kreiranja plana i programa za učenje stranog jezika prednost mora dati praktičnom segmentu učenja jezika, naspram teoretskog, što se u samoj nastavi potvrdilo kao veoma učinkovito i atraktivno među učenicima. Na tragu toga, smatramo da je potrebno revidirati planove i programe, kao i udžbenike arapskog jezika, koji se koriste u obrazovnim institucijama IZ-e u BiH. U tom kontekstu, pojedini autori (Lightbown\&Spada 2014: 353) smatraju da ,je žalosno da pojedina djela kreću od pogrešne pretpostavke da se razvoj drugog jezika zasniva samo na gomilanju pravila, jednog iza drugog".

Najrasprostranjenija metoda koja se primjenjuje u podučavanju arapskog jezika u obrazovnim institucijama $\mathrm{IZ}-\mathrm{e} \mathrm{u} \mathrm{BiH}$ jeste 
gramatičko-prevodilačka metoda (țarīqa al-naḥw wa tarğama), koja se bazira na savladavanju osnovne gramatike i prevođenju tekstova, kao mjerilo da je učenik / student uspješno shvatio i primijenio naučena gramatička pravila. Iako je ova metoda značajna i skoro neizbježna u prvim fazama učenja stranog jezika, insitiranje na njenoj primjeni $u$ kasnijim fazama predstavlja značajnu prepreku za brže usvajanje stranih jezika.

Mišljenja smo da bi bilo veoma efikasno kombiniranje ove sa drugim metodama, poput komunikativne metode (țarīqa țawāṣuliyya) kako bi se naučeno moglo primjenjivati u praksi, a u kasnijim fazama isključiti mogućnost komunikacije na nekom drugom osim jezika koji se želi naučiti. Ovakav pristup je znatno efikasniji i učenicima / studentima lakši, jer „konačno učenici ili studenti mogu opušteno razmišljati i komunicirati na stranom jeziku", kako to često vole istaći.

\section{Četvrti faktor: Udžbenik}

U slučaju arapskog jezika, trenutni kvalitet udžbenika u značajnoj mjeri zaostaje za udžbenicima za druge strane jezike. Ta činjenica je iznenađujuća, posebno imajući u vidu mogućnosti kojima raspolažu obrazovne institucije, ali i broj specijaliziranih institucija koje se bave ovom oblašću u arapskom svijetu.

Analizirajući udžbenike namijenjene učenicima medresa, poput Udžbenika arapskog jezika za prvi razred medrese ${ }^{3}$, nalazimo da je velik fokus stavljen na gramatiku, zanemarujući činjenicu je spomenuto gradivo namijenjeno učenicima koji do tada nisu imali nikakvog dodira sa leksikom, niti gramatikom arapskog jezika. Spomenuta literatura bi bila adekvatna za učenike drugog ili trećeg razreda, nakon što su uspjeli usvojiti osnovnu leksiku arapskog jezika, na koju bi mogli primijeniti gramatička pravila koja nakon toga usvajaju.

Prilikom izučavanja arapskog jezika veoma bitno je i učinkovito staviti fokus na tekstove iz Kur'ana i hadisa (izreka Muhameda, s.a.v.s.) jer je arapska kultura općenito značajno prožeta tim tekstovima, ali i zbog činjenice da su ishodi učenja na obrazovnim institucijama IZ-e u $\mathrm{BiH}$ vezani za spomenute izvore (Al-'Amīn 2008: 163.). S tim u vezi, u

\footnotetext{
${ }^{3}$ Halilović, Ahmed (2002), Udžbenik arapskog jezika za prvi razred medrese, ElKalem, Sarajevo.
} 
takvim grupama ili odjeljenjima treba akcentirati kur'ansko-hadisku terminologiju, jer je primarni cilj u njihovom izučavanju arapskog jezika upravo razumijevanje tih izvora i tekstova proizašlih iz istih. Zbog toga postoje posebni programi za izučavanje arapskog jezika poznatiji kao „Arapski jezik kroz Kur'an“" ${ }^{\text {, }}$, koji poseban akcenat stavljaju isključivo na kur'ansku leksiku ili na najfrekventnije riječi u Kur'anu.

Prema tome, program, kao i sam udžbenik, trebaju da ispunjavaju nekoliko bitnih uvjeta, kao što su:

a) da budu prilagođeni uzrastu učenika/studenata,

b) da budu interesantnog sadržaja, poput poučnih priča i tekstova koje će privući pažnju učenika / studenata,

c) da se tiču realnog života, poput internet sadržaja koji prate savremene tokove i prilike,

d) da nude korisne podatke, koji će osim jezičkog, biti spoznajnog i odgojnog karaktera (Ṭu'ayma 2004: 199).

\section{Peti faktor: Okruženje u kojem se realizuje nastava}

Idealno bi bilo da se strani jezik uči u zemlji u kojoj se on govori i među ljudima kojima je on maternji jezik. Upravo u takvom okruženju se jezik najlakše i najbrže usvaja, jer su usvaja aktivno, ali i pasivno. Međutim, s obzirom da to sebi većina ljudi nije u stanju priuštiti, onda se taj nedostatak pokušava nadomjestiti predavačima koji dolaze iz tog govornog područja, a ako ni to nije moguće, onda se na nastavi nastoji komunicirati isključivo na tom jeziku, kako bi se stvorio barem približan ambijent.

Također, ovdje bitno naglasiti još dvije veoma značajne stvari:

a) uvažavanje sredine, običaja i mentaliteta osoba koje uče strani jezik, jer određene nastavne cjeline ili tekstovi nisu adekvatni za pojedine sredine, zbog veoma izraženih kulturoloških razlika. Ovo se odnosi na početne faze usvajanja stranog jezika, dok je na naprednim nivoima

\footnotetext{
${ }^{4}$ Poput programa „Arabic Through the Quran“ na www.memrise.com ili „Arabic of the Quran“" na www.udemy.com
} 
preporučljivo isticati specifičnosti arapske kulture, običaja i mentaliteta, kako bi se postigao i kulturološko-edukacijski efekat,

b) raznolikost prostorija u kojima se odvija nastava, poput razreda, fonolabaratorije, biblioteke ili praktičnog časa u prirodu, jer je promjena ambijenta veoma bitna za razbijanje monotonosti, ali i za lakše usvajanje određenih tematskih cjelina ukoliko se nastava realizuje $\mathrm{u}$ adekvatnom i odgovarajućem prostoru.

Često se upravo ovaj detalj nema u vidu i učenici / studenti gube volju $\mathrm{s}$ obzirom na opći monotoni pristup nastavnom procesu u cjelosti.

\section{Kontinuiranja nadogradnja i traganje za novim metodama}

Nastavnik stranog jezika, prije svega mora biti ambiciozan i stremiti da jezik kojeg predaje zauzme značajno mjesto u nastavi i životu učenika / studenata kojima ga treba prenijeti.

Rezultat te ambicioznosti jeste permanentno traganje za novim metodama $^{5}$, koje će unaprijediti njegov rad i učiniti ga korisnim i u isto vrijeme zanimljivim, a to je u današnjim okolnostima veoma teško postići, s obzirom na sva tehnološka dostignuća koja su dostupna mladom čovjeku, koja, umjesto da unapređuju njegove spoznaje, one ga ometaju i značajno limitiraju njegove intelektualne mogućnosti. Međutim, koliko su tehnološka dostignuća remetilački faktor, toliko mogu da budu prednost, jer se putem njih može značajno unaprijediti nastava stranog jezika (Handley 2017: 153).

Koraci koje možemo predložiti u nastavi stranog, a u našem slučaju arapskog jezika, kao potencijalna kreativna rješenja, koja razbijaju monotoniju na nastavi su:

a) pretpostavljene situacije u kojima je neophodna upotreba stranog jezika (poput susreta sa strancem koji ne poznaje naš jezik),

b) narodne izreke ili šale koje prevodimo sa našeg na strani jezik ili obratno,

\footnotetext{
5 Jedno od korisnih djela koja nam mogu pomoći na planu usvajanja novih jezika, a samim tim i njihovom podučavanju jeste djelo Fast easy way to learn a language od Billa Handleya.
} 
c) prepričavanje poznatog događaja, priče ili filma na stranom jeziku,

d) različiti oblici kreativnih igara $^{6}$, koje odgovaraju uzrastu grupe sa kojom učimo strani jezik ${ }^{7}$,

e) debatska natjecanja između nekoliko grupa, gdje do izražaja dolazi natjecateljski duh, a mogu se koristiti kod naprednih nivoa, itd.

Jedan od učinkovitih načina gdje se nastavnici mogu upoznati sa novim pristupima i novim metodama jeste i organizovanje stručnih seminara za nastavnike arapskog, ali i svakog drugog stranog jezika, gdje postoji velika mogućnost usvajanja novih vještina i spoznaja od stručnjaka iz ove oblasti, ali i kroz razmjenu iskustava sa ostalim kolegama, koji svojom individualnom kreativnošću mogu ponuditi nove modele i pristupe u nastavi. Smatram da na tim seminarima treba dati prostora svim učesnicima da ponude metode u čiju su se učinkovitost uvjerili u svom radu.

\section{Zaključak}

Nakon svega iznesenog možemo konstatovati da učenje stranih jezika, a naročito arapskog zbog brojnih razlika između njega i bosanskog jezika, iziskuje naporan i mukotrpan rad, mnogo strpljenja i odricanja.

Ključnu i centralnu ulogu u procesu usvajanja stranog jezika igra kvalitetno educiran nastavnik, koji svojim vještinama, svojom širokom naobrazbom i kreativnošću uvijek uspijeva motivirati učenike / studente da izučavaju strani jezik. To je posebno značajno u slučajevima kada se strani jezik izučava kao predmet predviđen planom i programom, u čijem odabiru učenici ili studenti nisu imali udjela, što je slučaj kod većine stranih jezika.

Nastavnik treba da uspješno upravlja procesom učenja stranog jezika, uzimajući u obzir da ostali faktori budu u službi unapređenja kvalitete nastave.

\footnotetext{
${ }^{6} \mathrm{O}$ čemu bi trebali pisati poseban rad, s obzirom na značaj same teme i uloge koju igre mogu da imaju u procesu usvajanja gradiva, ali i razbijanju monotonije koja je veoma prisutna na satima učenja stranih jezika.

${ }^{7}$ Više o ovome vidi: Hadžić, Muharem, Metodika arapskog jezika, BZK „Preporod““ Zenica, Zenica, 1999. str. 115.
} 
Pored nastavnika, veoma značajnu ulogu ima motiviranost i intelektualna sposobnost učenika / studenta, zatim plan i program i literatura koja se u tom procesu koristi, ali i okruženje u kojem se nastava stranog jezika realizuje.

Kvalitetan nastavnik stranog jezika nikada neće prestati tragati za novim metodama, kojima bi unaprijedio svoj rad i uvijek će se dodatno educirati i biti otvoren za nove pristupe i upotrebu novih tehnoloških pomagala $\mathrm{u}$ radu.

\section{Literatura}

1. Al-'Amīn, 'Isḥāq (2008), Manhăg 'Isesko li tadrīb mu 'allimī allug்a al- 'arabiyya li gayr al-nātiqīin bihā, Rabāṭ.

2. Alispahić, Zehra (2007), „O problemima u učenju arapskog jezika“, Pismo - Časopis za jezik i književnost, No. 05, Bosansko filološko društvo, Sarajevo.

3. Hadžić, Muharem (1999), Metodika arapskog jezika, BZK „Preporod“" Zenica, Zenica.

4. Halilović, Ahmed (2002), Udžbenik arapskog jezika za prvi razred medrese, El-Kalem, Sarajevo.

5. Handley, Bill (2017), Ta 'allam luğa ğadīda bi sur'a wa suhūla, Al-Qāhira.

6. Lightbown P. M., Spada N. (2014), Kayfa nata 'allam al-luḡāt, Al-Markaz al-qawmiyy li al-tarğama, al-Qāhira.

7. Tu'ayma, Rušdī Aḥmed (2004), Al-Mahārāt al-lug̉awiyya, Dār al-fikr al-`arabiy, al-Qāhira. 


\section{Hajrudin Hodžić, PhD}

University of Bihac

Islamic pedagogical faculty

bajrudinhodri@@gmail.com

Original scientific article

\section{IMPORTANT FACTORS FOR SUCCESS IN LECTURING ARABIC LANGUAGE}

\section{ABSTRACT}

Benefits and uses of the knowledge of a foreign language are immeasurable and represent a significant motive for learning foreign languages, especially those of the world's most prevalent. Learning any foreign language is a tough and painstaking process, which requires a lot of patience and renunciation. However, the moment when most of a language is adopted, the feeling of fatigue is lost burdened the person who gradually adopted him. There are many factors that can affect the efficiency and speed of language acquisition, but the main one the role in the whole process is taken by the teacher, who needs to successfully manage the learning process, in order to get the best possible results. The aim of this paper is to indicate the most important factors for success in Arabic language teaching, then to review the current experience in the field of Arabic language teaching, but also to offer certain ideas and approaches that will help develop new skills among teachers Arabic, but also any other foreign language.

Keywords: Arabic language, methods, success factors, teaching, foreign language 
الدكتور المحاضر خيرالدين هوجيتش

\section{عوامل هامة للنجاح في تدريس اللغة العربية}

\section{الخلاصةة}

فوائد معرفة لغة أجنبية ومزاياها لا حصر لها، وتمثل هذه الفوائد دافعًا مهمًا لتعلّم

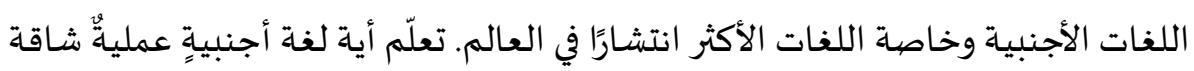
تتطلب الكثير من الصبر والتضحية، ولكن في اللحظة التي يتم فيها استيعاب الجزء الأكبر

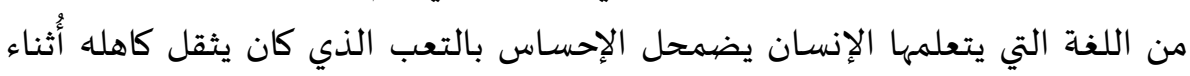
التعلم.

هناك العديد من العوامل التي يمكن أن تؤثر على سرعة تعلم اللغة وجودة إتقانها

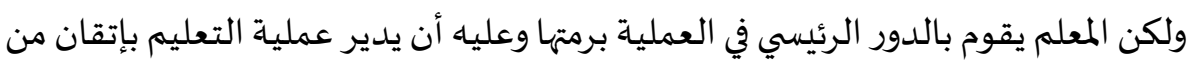
أجل الحصول على أفضل النتائج الممكنة.

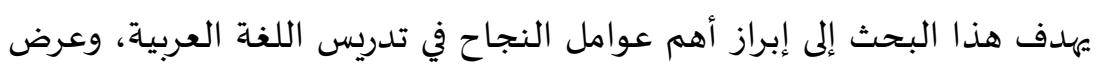

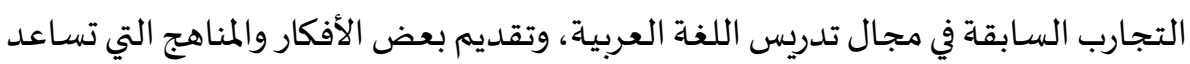
على تطوير مهارات جديدة لدى معلم اللغة العربية أو أية لغةٍ أجنبةٍ أخرى.

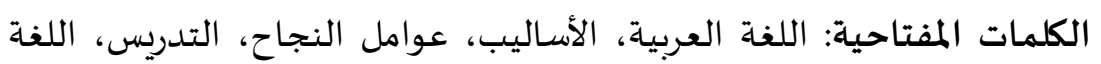

